Canadian Journal of Higher Education

Revue canadienne d'enseignement supérieur

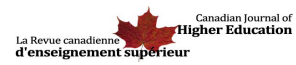

\title{
The Relationship Between Experiential Learning and Career Outcomes for Alumni of International Development Studies Programs in Canada
}

\author{
Rebecca Tiessen, Kate Grantham et John Cameron
}

Volume 48, numéro 3, 2018

URI : https://id.erudit.org/iderudit/1057127ar

DOI : https://doi.org/10.7202/1057127ar

Aller au sommaire du numéro

\section{Éditeur(s)}

Canadian Society for the Study of Higher Education

ISSN

2293-6602 (numérique)

Découvrir la revue

\section{Citer cet article}

Tiessen, R., Grantham, K. \& Cameron, J. (2018). The Relationship Between Experiential Learning and Career Outcomes for Alumni of International Development Studies Programs in Canada. Canadian Journal of Higher Education / Revue canadienne d'enseignement supérieur, 48(3), 23-42. https://doi.org/10.7202/1057127ar

\section{Résumé de l'article}

Le présent article s'intéresse aux liens entre l'apprentissage expérientiel et les parcours de carrière des diplômés en Études de développement international (EDI) du point de vue des anciens étudiants. Les résultats d'une enquête nationale à laquelle ont répondu 1901 anciens des programmes EDI à travers le Canada sont présentés ici. Analysant les données de cette étude, nous soulevons les questions suivantes: 1) Quelles sont les pratiques d'apprentissage expérientiel considérées les plus importantes par les anciens des programmes d'EDI? 2) Comment perçoivent-ils les liens entre l'apprentissage expérientiel et les possibilités de carrière? Nous avançons que la collecte des opinions des diplômés en EDI sur les liens entre l'apprentissage expérientiel et les parcours de carrière informera les possibilités actuelles des programmes et mettra en évidence les liens entre l'apprentissage intégré au travail et la réussite professionnelle dans ce domaine. 
Canadian Journal of Higher Education Revue canadienne d'enseignement supérieur

Volume 48, No. 3, 2018, pages 23 - 42

\title{
The Relationship Between Experiential Learning and Career Outcomes for Alumni of International Development Studies Programs in Canada
}

\author{
Rebecca Tiessen \\ University of Ottawa \\ Kate Grantham \\ McGill University \\ John Cameron \\ Dalhousie University
}

\begin{abstract}
In this paper, we explore the relationship between experiential learning and career outcomes for international development studies (IDS) graduates from the perspective of program alumni, by presenting the results of a national survey completed by 1,901 IDS alumni across Canada. Employing study data, we answer the following research questions: (1) What do IDS alumni consider important experiential learning opportunities? and (2) What is the perceived relationship between experiential learning and career outcomes? We argue that documenting IDS graduate perspectives on the relationship between experiential learning and career paths can inform current program opportunities and highlight the relationship between work-integrated learning and career success in this field.
\end{abstract}




\section{Résumé}

Le présent article s’intéresse aux liens entre l'apprentissage expérientiel et les parcours de carrière des diplômés en Études de développement international (EDI) du point de vue des anciens étudiants. Les résultats d'une enquête nationale à laquelle ont répondu 1901 anciens des programmes EDI à travers le Canada sont présentés ici. Analysant les données de cette étude, nous soulevons les questions suivantes: 1) Quelles sont les pratiques d'apprentissage expérientiel considérées les plus importantes par les anciens des programmes d'EDI? 2) Comment perçoivent-ils les liens entre l'apprentissage expérientiel et les possibilités de carrière? Nous avançons que la collecte des opinions des diplômés en EDI sur les liens entre l'apprentissage expérientiel et les parcours de carrière informera les possibilités actuelles des programmes et mettra en évidence les liens entre l'apprentissage intégré au travail et la réussite professionnelle dans ce domaine.

\section{Introduction}

International development studies (IDS) students enrolled at Canadian universities and colleges have a large range of experiential learning options to choose from, including internships, co-operative education (co-op), practicum placements, community service learning, study abroad, volunteer abroad, and field schools, to name a few. These programs often involve a combination of educational and practical work experience, and provide students with opportunities to further the knowledge learned in the classroom, develop new skillsets, and network with potential employers. International experiential learning opportunities are also available to IDS students who want the chance to travel and work with a university or development organization in another country, often in the Global South. One of the frequently stated goals of experiential learning programs by universities and colleges is to cultivate graduates who are "job ready" and equipped for working in the new economy (Study Group on Global Education, 2017). However, very little is known about the career outcomes of IDS students in Canada, particularly in relation to the impact experiential learning programs have had on preparing students for careers in international development and related fields.

Research on the relationship between experiential learning and career outcomes for IDS students has largely focused on the perspectives of universities, employers, and current students, with far fewer studies examining outcomes from the perspective of program graduates, and the few studies that do consider graduate perspectives focus narrowly on employment and income data with little attention to questions about how experiential learning influences career outcomes (Ferguson \& Wang, 2014; Sattler \& Peters, 2013). Yet documenting graduate perspectives is key to understanding the impact of experiential learning on students' career paths and career success. There are important debates regarding whether experiential learning programs effectively prepare students to access jobs in the international development sector, or other industries, and to perform well in those jobs (Matthews, Dorfman, \& Wu, 2015; McRae, Ramji, Lu, \& Lesperance, 2016). The comparative benefits of different experiential learning programs on employment outcomes are also unknown. Able to draw on their own personal and work experiences, IDS graduates are in a strong position to provide insight into these issues. 
In this paper, we explore the relationship between experiential learning and career outcomes for IDS students from the perspective of program alumni, by employing the results of a national survey conducted on the career paths of IDS graduates in Canada. We begin by identifying the different definitions and types of experiential learning options open to IDS students, and what the literature says about these kinds of programs and their relationship to education and career outcomes. After reviewing the existing literature, we present the results of the national career paths survey. Employing study data, we answer the following research questions: (1) What do IDS alumni consider important experiential learning opportunities? and (2) What is the perceived relationship between experiential learning and career outcomes? In closing, we point to possible applications of study findings and areas for further research.

\section{Literature Review}

\section{Different Definitions and Types of Experiential Learning Options Open to IDS Students}

"Experiential learning" is an umbrella term used to describe an array of approaches to practice-based education, usually involving student placements in a workplace or organization in their field of study. Experiential learning as a component of higher education programs was popularized through the work of educational theorist David Kolb (1981, 1984). The experiential learning model first developed by Kolb and Fry (1974) emphasizes student learning through an iterative cycle involving experience, reflection, and application. Put simply, experiential learning programs attempt to complement and to further students' classroom learning by providing them with "hands-on experience." For today's university and college students, this can take a variety of forms, including internships, co-op or practicum placements, community service learning, and field schools, to name a few examples. For students enrolled in IDS programs, experiential learning opportunities can also include an international component or placement, like study abroad or volunteer abroad. While the breadth of experiential learning options makes it difficult to generalize about their impacts on student learning or on employment outcomes, the reflections of IDS graduates on experiential learning programs within this single field of study do offer valuable insights for program design in IDS and other fields.

At present in Canada, there are more than 20 universities and colleges that offer IDS degrees at either the bachelor's, master's, or doctoral levels (Tiessen \& Cameron, 2017, p. 7), and most "have their own experiential learning programs with dedicated faculty members to coordinate and deliver these programs, at times travelling with students abroad" (Tiessen \& Huish, 2014, p. 9). Canadian IDS programs are witnessing a burgeoning interest in experiential learning among students, as evidenced by the growing number of program options and enrollment figures (Tiessen, 2018, p. 23). The popularity of these programs is further supported by research and government reports linking experiential learning to improved job preparedness and employability among students (Association of Universities and Colleges Canada [AUCC], 2014; Canadian Bureau for International Education [CBIE], 2014, 2016; Ferguson \& Wang, 2014). From the perspective of universities and colleges, offering experiential learning opportunities can enhance their reputation and serve as a marketing tool to attract students who want to be competitive in today's workforce (Grantham, in press; Sharpe, 2015). 


\section{What the Literature Says About These Kinds of Programs and Their Rela- tionship to Education}

Much existing research draws positive links between student participation in experiential learning programs and educational outcomes (Clayton, Bringle, \& Hatcher, 2013; Eyler \& Giles, 1999; Eyler, Giles, Stensen, \& Gray, 2001; Warren, 2012). For example, participation in experiential learning is believed to further the knowledge learned in the classroom by reinforcing theories and concepts in a real-world setting (Kolb, 1981, 1984; Kolb \& Fry, 1974). Astin, Vogelgesang, Ikeda, and Yee (2000) explore the comparative effects of community service and course-based service learning on the cognitive and affective development of undergraduate students. The authors find that participation in community and service learning shows positive effects on student academic outcomes like grade point average, writing, and critical thinking skills, particularly when such service is conducted in the context of a university or college course. According to Astin et al., "The frequency with which professors connect the service experience to the course subject matter is an especially important determinant of whether the academic material enhances the service experience, and whether the service experience facilitates understanding of the academic material" (p. 3). Moreover, when students are able to process their service experience through facilitated classroom discussion they achieve improved educational outcomes. These findings corroborate several recent studies using different samples and methodologies (Jameson, Clayton, \& Ash, 2013; Lockeman \& Pelco, 2013; Nevison \& Pretti, 2016).

Not all experiential learning programs provide equal educational benefits to students. Stirling et al. (2017) examine the characteristics of internships in Ontario colleges and universities to assess the congruence between the components of these internships and Kolb's (1984) experiential learning framework. Information from 44 Ontario universities and colleges, including 369 internship program webpages and 77 internship course outlines, was analyzed. The findings indicate that most internship programs overemphasize the practical aspect of students' experience at the expense of linking theory to practice. To improve programs, Stirling et al. (2017) recommend that explicit learning activities be established to help students integrate and connect their internship experience with relevant theory and coursework (p. 41). Other research draws similar conclusions about the need to link theory to practice in order for students to derive maximum educational benefit from experiential learning programs (Eames \& Coll, 2010; Nevison, Drewery, Pretti, \& Cormier, 2016; Sides \& Mrvica, 2007; White \& Devereux, 2017), including the ability to think critically about what "responsible development" means and how it can be fostered (Brown, 2015).

\section{What the Literature Says About Experiential Learning and Career Success}

Research by Mate and Ryan (2015) suggests that experiential learning promotes career success by helping students to develop new skillsets that cannot be learned in a classroom setting. The authors argue that the transition from university to the workforce can be made easier by experiential learning programs, like co-op, because these programs help students to develop transferrable skills and to cultivate a professional identity and what they term "career resiliency." Other studies corroborate that experiential learning enhances graduate employability by way of improving skill outcomes, such as teamwork, communication, self-management, and problem solving (Billett, 2011; Eyler et al., 2001; Martin, Rees, \& 
Edwards, 2011). Research conducted with students themselves also finds that skill development, in so far as it contributes to employment outcomes or career advancement, is considered among the chief benefits of participating in experiential learning programs (Downey, Kalbfleisch, \& Truman, 2002; Tiessen, 2018, p. 80; Tiessen \& Heron, 2012).

Apart from skills development, research emphasizes the benefits of experiential learning programs that expose students to the "real world-of-work." Jackson's (2013) analysis of the role of work-integrated learning programs like co-op, internships, and practicum placements in improving undergraduate employability, finds that these programs help to build students' confidence in their capabilities, give students a greater appreciation of the importance of employability skills, and introduce students to workplace norms and culture. Other researchers agree that experiential learning programs can improve students' knowledge of appropriate workplace conduct by exposing them to the behaviour of co-workers and supervisors (Bowen, 2016; Dall'Alba, 2009; Nystrom, 2009). Closely related to this concept of workplace exposure, the networking potential of such programs has been cited as a key factor in students' career development and early career success (Mate \& Ryan, 2015).

A small subdivision of studies on the career outcomes of experiential learning examines this topic from the perspective of employers (Gardner, Gross, \& Steglitz, 2008; Kock \& Weeks, 2015; Sternberg, 2013). One of the positive benefits often attributed with participation in experiential learning programs is the importance employers place on previous work experience during the recruitment and hiring process (Bond et al., 2009). Many universities and colleges have spun this message into their promotional and recruitment materials by documenting their alumni's post-graduation experiences, particularly making note of career outcomes and sectors in which alumni are now employed.

For IDS students, recent studies suggest that international placements may enhance the development of skills and competencies that are increasingly in demand for work in the development sector (Fee \& Gray, 2011; Study Group on Global Education, 2017, Figure 2.2). For this reason, time spent engaged in experiential learning abroad is frequently advertised by universities as a valuable attribute in the eyes of international development employers (Lewin, 2009; Sauntson \& Morrish, 2010; Sharpe, 2015). Interestingly, research conducted with employers themselves counters this idea. Kock and Weeks (2015) set out to identify the job-related competencies needed for entry-level work in international development. They administered an online questionnaire to NGO staff in management and administrative positions and found that years of foreign work experience did not play an important role in hiring decisions (p. 30). Similarly, survey research conducted by Gardner et al. (2008) found that employers do not necessarily value the study abroad experience as highly as other co-curricular activities that students can choose to participate in. In some cases, the limited value that employers place on international experiences is due to their lack of knowledge about the nature and benefits of study or volunteer abroad programs. Many of the employers surveyed by Gardner et al. mentioned that these programs were not available to them during their undergraduate days or they were not aware these programs existed (p. 2). In other cases, employers reported that students were unable to describe the value or relevance of their international experience when asked to do so in an interview setting, and they were unprepared for how to articulate this to employers (p. 4). These findings demonstrate that "simply having an international experience does not necessarily lead to the development of capabilities that result in career success" (McRae et al., 2016, p. 377). 


\section{Critical Scholarship}

A growing body of critical literature is concerned with the consumerist orientation of experiential learning programs that are advertised and promoted to students as opportunities for career development (Jorgenson \& Shultz, 2012; Qiubo, Shibin, \& Zha, 2016). The use of experiential learning as a marketing tool through which universities can boost enrollment figures is particularly problematic in the context of international programs that place students with organizations serving poor and vulnerable communities in the Global South. Studies have raised concerns around the potentially exploitative nature of these programs, which can produce one-sided benefits for Global North university students (Palacios, 2010; Sharpe, 2015). Tiessen and Huish (2014), for example, warn that student participation in international experiential learning programs "should not be primarily motivated by experimental or testing opportunities in which communities in the Global South become laboratories for young, privileged youth from the Global North to test a career choice or academic background" (p. 285). Other authors have articulated similar post-colonial critiques of international experiential learning (Larsen, 2015; MacDonald, 2014; Perold et al., 2012; Thomas \& Chandrasekera, 2014).

There are also important structural challenges inherent in experiential learning programs that are only available to students with the financial means to participate in them (Tiessen \& Huish, 2014, p. 287; Sattler \& Peters, 2013). Internships and co-op programs are time-intensive commitments and therefore difficult to combine with part-time work, and international opportunities can have high travel costs associated with them that students are responsible to pay. Barriers to participation also impact students unevenly, with male students, students of colour, students with disabilities, lesbian, gay, bisexual and transgender students, single parents, mature students, first-generation students, and Indigenous students disproportionality less likely to participate in experiential learning programs, and international opportunities in particular (CBIE, 2014; Grantham, in press; Thirlof, 2014; Universities Canada, 2016a). With this in mind, the Study Group on Global Education (2017) reports, as one of three top priorities for Canada, making international learning accessible to students of all backgrounds:

The benefits of international learning-improved academic outcomes, career prospects, employability skills-appear to be strongest for students who come from less-advantaged backgrounds. It is therefore imperative that students from lowincome backgrounds and underrepresented groups have access to these experiences. (n.p.)

The broad range of ethical issues that must be addressed in international experiential learning are examined in depth in the literature (Karim-Haji, Roy, \& Gough, 2016; MacDonald \& Tiessen, in press; Tiessen, 2018; Universities Canada, 2016b). While the focus on a range of ethical considerations is important and more thoroughly addressed, the relationship between experiential learning and career outcomes remains an under-researched field of study.

Looking to the Canadian context, very little is known about the career paths and employment outcomes of IDS graduates, particularly in relation to the impact of experiential learning. The diversity of experiential learning definitions, options, and timeframes 
makes evaluation and measurement of outcomes, especially longer-term employment outcomes, exceedingly difficult (Grantham, in press; Tiessen, 2012). The absence of national data has also been identified as contributing to a lack of knowledge on this issue (Bennett, 2009; Tiessen \& Huish, 2014, p. 7; Universities Canada, 2016a).

\section{Research Methods}

In 2016, researchers Rebecca Tiessen and John Cameron and a Steering Committee comprised of members of the Canadian Association for the Study of International Development (CASID) and the Canadian Consortium of College and University Programs in International Development Studies (CCCUPIDS), respectively, set out to gather data and better understand the relationship between IDS education and subsequent employment experiences of graduates from IDS programs at Canadian universities and colleges. Specifically, they wanted to understand the kinds of employment (self-, NGO, private-sector, government, etc.) that graduates obtained, and how graduates perceive the relationship between their employment and their studies in international development.

The data presented and analyzed in this paper were collected in a national online survey of IDS graduates from 14 universities and colleges in Canada. The participating programs were selected based on their student population size, the number of years the program has been offered, and other variations in program design and regional location. The survey was conducted in French and English and was available for graduates to complete between March and May 2016. It included 146 questions about career paths, employment history, and educational experiences, as well as an open-ended question that allowed IDS graduates to narrate, in their own words, their post-graduation employment experiences. The survey was distributed by each of the participating IDS programs directly to their respective alumni. An open-access version of the survey was also promoted through CASID and other networks, which generated responses from 351 IDS graduates, the vast majority of whom had studied at one of the 14 participating institutions.

In total, the researchers received 1,901 completed survey responses, with 520 relevant responses to the open-ended question. The data from the quantitative section of the survey were analyzed to examine possible correlations between specific features of a graduate's education and their subsequent employment experiences. The data from the open-ended qualitative section of the survey were coded and analyzed to identify key trends in the career paths of IDS graduates and their reflections on their post-secondary education.

\section{Findings and Discussion}

Analysis of the quantitative and qualitative survey data produced six central findings regarding the career paths of IDS graduates, including information about job satisfaction, education levels, experience breaking into the job market, barriers to employment, the skills and competencies required to find employment, and the impact of IDS education on graduates' lifestyles and worldviews. In this section, we will focus on the two findings (out of those six) that are specific to experiential learning. Specifically, we employ study data to answer the research questions: (1) What do IDS alumni consider important experiential learning opportunities, and (2) What is the perceived relationship between experien-

tial learning and career outcomes? For further reading, see the full report entitled The Career Paths of IDS Graduates in Canada (Tiessen \& Cameron, 2017). 


\section{Participation Rates of IDS Graduates in Experiential Learning Programs}

Figure 1 reports on the participation rates of IDS graduates in a variety of experiential learning programs (Survey Question 1.7). It indicates that three-quarters of IDS graduates took part in practice-oriented forms of learning as part of their education. The data presented in Figure 1 are significant when analyzed in the context of national data, which indicate that less than $3 \%$ of university students take part in an overseas learning experience as part of their university education (CBIE, 2016), and that only 12\% participate in co-op programs, which are highly concentrated in Science, Technology, Engineering and Math (STEM) fields (Ferguson \& Wang, 2014, Table A18). It appears that IDS students participate in work-related and experiential learning and study abroad opportunities in relatively large numbers when compared with students in other fields of study.

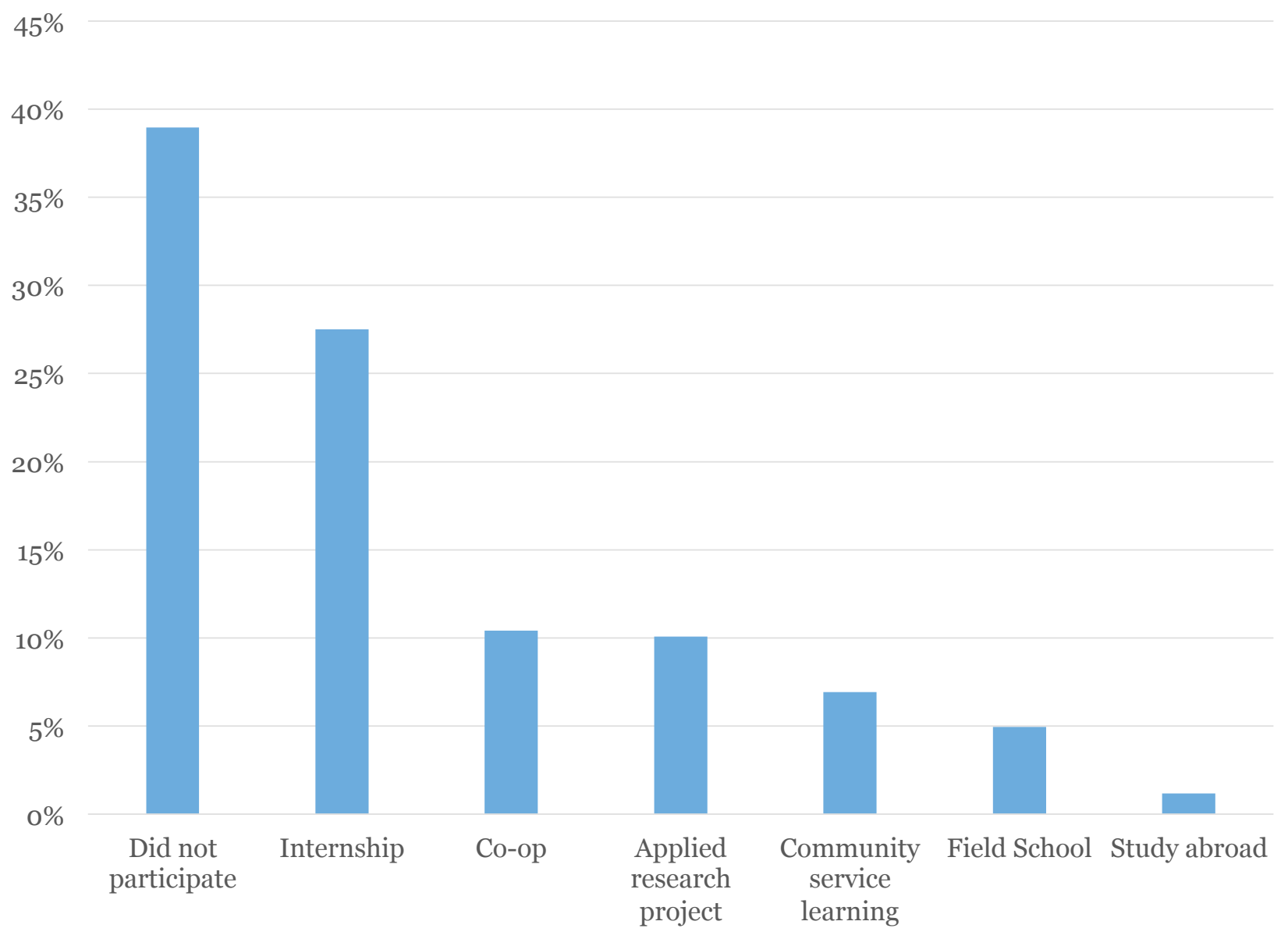

Figure 1: Did IDS graduates participate in experiential learning programs during their studies?

The types of experiential learning opportunities mentioned most often in the openended responses were internships, co-op placements, study abroad, and volunteer abroad. This closely resembles the quantitative data presented in Figure 1, with the exception of co-op placements, which were mentioned more frequently in the open-ended responses compared to the number of graduates who participated in co-op during their IDS degree. 
The reason for this discrepancy is that many graduates commented on the value of co-op placements for helping students to access jobs in international development, even if they did not participate in co-op programs themselves, or if it was not available to them during their degree. Fewer than $12 \%$ of all participants in this study completed co-op placements, but it was among the most frequently mentioned forms of experiential learning in the open-ended question, surpassed only by internships. International opportunities including study abroad and volunteer abroad were also mentioned often in the open-ended data, with many graduates participating in these programs and commenting on their value in helping students gain "international experience," which is now required for most entry-level jobs in the international development sector.

\section{Does Work-Related and Experiential Learning Help to Find a Job?}

Despite relatively high participation rates, the perspectives of IDS graduates on the value of experiential learning programs for finding jobs in their chosen fields of study were ambiguous. Less than half of the respondents agreed (19.2\%) or strongly agreed (21.0\%) that these practice-based programs were helpful for obtaining a job (Survey Question 2.1.6).

When asked to select the practice-based learning options that they felt were most valuable, graduates very clearly highlighted "internships" (48\% of respondents), with co-op work programs ranking a distant second (14\%) and "applied research projects" ranking third (13\%). An additional 10\% of respondents selected internships in combination with other practicum options (Figure 2). This data should also be interpreted with caution, as they represents the perceptions of IDS graduates of the relative importance of learning experiences that they did not necessarily participate in. For example, some graduates who did not take part in internships or co-op programs ranked them as very important for finding a job, and later elaborated on this perception in their open-ended responses. With fewer than $12 \%$ of all participants in this study completing co-op placements, it is important not to draw conclusions about employment outcomes and this form of practical work experience. Nevertheless, the data do provide some indication of student perceptions of the relative value of different practice-based learning options, which administrators may choose to consider when investing time and resources in the creation of new initiatives.

Figure 3 indicates that $42 \%$ of IDS graduates agreed or strongly agreed that their degree prepared them for entry-level work in international development or a related field, while $31 \%$ disagreed or strongly disagreed that their degree provided sufficient preparation. Respondents highlighted the value of acquiring "soft" transferrable skills for finding jobs in their current fields-skills such as writing, critical thinking, and communication. However, they also highlighted other skills and competencies that employers are looking for, which large numbers did not acquire as part of their IDS degrees. Competency in a second language stands out as a valued skill. Other skills that IDS graduates highlighted included interpersonal skills (e.g., teamwork), cross-cultural skills, computer skills (especially Microsoft Office), budgeting and financial management skills, and project management. Some of these skills can be learned through coursework, but most are more likely to come from time spent abroad or working directly with a development organization. These responses highlight that an undergraduate degree in IDS, on its own, may not be sufficient preparation for finding employment. 
$60 \%$

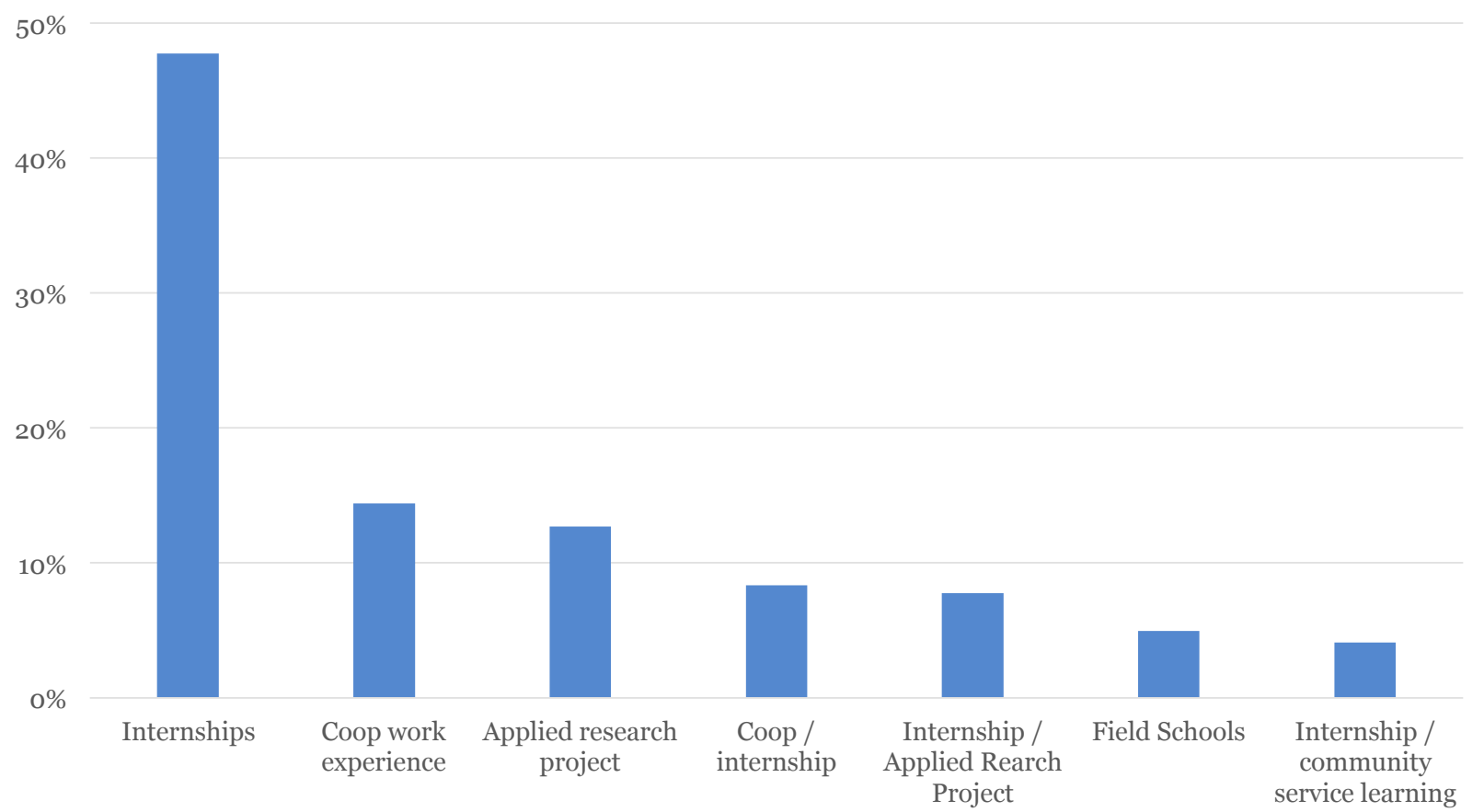

Figure 2: Which practice-based experiential learning programs were most helpful for obtaining work?

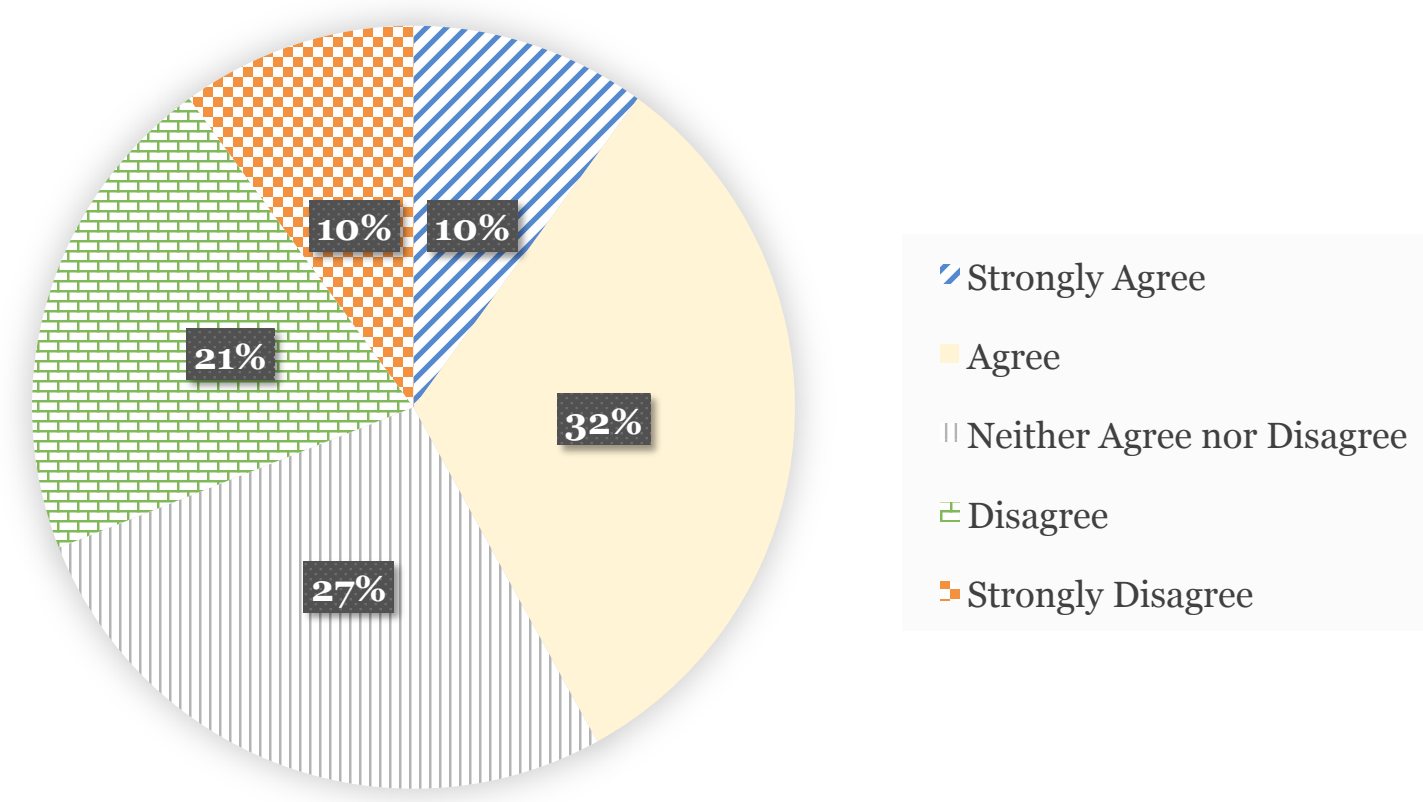

Figure 3: My IDS training prepared me for entry level work in international development (or a related field) 
A significant number of open-ended responses (16.7\%) highlighted that IDS programs in Canada do not adequately prepare students for the workforce, and that more practical "real-world training" is necessary. To better align IDS programs with job-market expectations, many graduates feel that co-op placements, internships, and other forms of international development work experience should be made widely available to students in IDS programs-or even made mandatory offerings in IDS programs:

Providing work experience (as a volunteer or intern) while still in the IDS program is extremely valuable for potential graduates. These opportunities provide the students with practical experience and understanding of the sector, as well as build a network. (Respondent 162)

A co-op or internship placement should be a mandatory part of every international development program. There should also be a stronger focus on research methods. Students should also learn more practical workplace skills that they can put on their resume rather than just theory. (Respondent 1564)

Since I chose to relocate to a developing country for employment opportunity, I found quite a lot of options existed within my chosen field. I did, however, have to acquire skills along the way, such as report writing/proposals for funding, as well as learning to conduct trainings for organizations working at the grassroots level. If some of this had been covered during my degree course in some way it would have greatly helped in building upon, rather than acquiring through experience. (Respondent 48)

I did not have the opportunity to do a co-op program but I would make this my top recommendation to anyone pursuing a degree now. (Respondent 65)

As there are a relatively small number of jobs available in Canada's international development sector, and most expect previous work experience, more could be done to help prepare graduates for competition in a highly demanding job market. Increasing experiential learning opportunities with development organizations is considered one way that IDS programs can prepare students for entry-level work in international development as well as other related fields. Results from Canada's 2013 National Graduates Survey underscore the value of co-op programs for helping students find quality jobs, indicating that college and university students who participate in co-op go on to see higher employment rates, earnings, and occupation-to-field-of-study matches than those who do not (Ferguson \& Wang, 2014).

Over a third of graduates (33.6\%) who responded to the open-ended question commented on the difficulties they have faced breaking into the international development sector in Canada after graduating from an IDS program. A frequently reported barrier to obtaining work is the limited number of highly competitive jobs in Canada, often restricted to major cities like Ottawa, Toronto, or Montreal. It is perceived that these jobs typically go to applicants with previous work experience and existing personal connections at an organization, or to those who have the economic means to accept unpaid internships or volunteer work before eventually obtaining a paid position. The following survey responses capture this perception: 
I quickly found that you need connections, technical skills, and experience to work in a field like IDS. My classmates at McGill who had connected family members got jobs easily, it was very difficult for everyone else. (Respondent 45)

I honestly feel a bit stuck. The internship I completed as part of my ID degree only gave me six months of international experience, yet most jobs want two to five years or more before they'll consider you. I've seen many friends with wealthy parents who pay their way take unpaid jobs to try to get that experience, but financially, that's something I just can't do.... It just seems like there's not a way to get that international experience if you're not already privileged enough to be able to finance it on your own. (Respondent 26)

I would have liked to provide feedback that my university did not offer co-op/ internships or do a very good job at engaging with undergraduate students to find meaningful post-graduation employment. The sentiment seemed to be "volunteer with an international organization long enough, and someone will eventually hire you." The reality was, there are no entry-level international development jobs unless you were lucky enough to not have student loans. (Respondent 140)

The experiences of respondents who report a smooth and successful career path in international development corroborate the idea that economic and social privilege impact on employment:

I am very fortunate to be working where I am and in the field I wanted to work in. I feel like I am one of the very few who was able to do this. I was connected to the CEO of my company as my mother used to work for him in a different field 30 years ago. I am not sure what I would be doing or if I would be working in this field and on this career trajectory if I did not make that connection and was not given that chance by my employer. (Respondent 499)

I was lucky and privileged to graduate without debt and thus take low-paying or stipend-based employment/internships in order to gain international experience and experience in general. (Respondent 669)

The structural barriers to entering the international development job market are particularly demonstrative in this context. Survey research conducted with Finnish IDS students and program alumni highlights similar concerns about an increasingly competitive and narrowing international development job market in Europe, making entry into the field more difficult (White \& Devereux, 2017, p. 17).

Increasing opportunities for students to participate in experiential learning placements for course credit is considered one strategy that can level the playing field for students without personal connections or the economic ability to accept unpaid internships or volunteer work temporarily. However, economic barriers also prevent students from participating in these opportunities, particularly international programs which can be expensive and require students to take time away from school and work:

The largest barrier I faced in finding work directly related to IDS was my inability to participate in an unpaid or extremely low-paying internship at home or abroad. 
I did not have the funds to support myself without pay, especially considering the international travel costs involved in most internships. This prevented me from obtaining job experience and network connections to be hired into a position directly related to development studies. (Respondent 259)

The major issue is receiving a response after submitting my resume. None have followed up. The biggest factor, I think, is my minimal experience in the field and the fact that I have never volunteered internationally. I would never be able to do that because it's not paid and I wouldn't be able to support myself. (Respondent 146)

Students from low-income backgrounds do not get the same opportunities as students from privileged backgrounds. There are very little to no financial assistance to students from low-income backgrounds who want to volunteer abroad or have some form of work experience abroad. (Respondent 218)

To address this issue, it is suggested by respondents that universities can do more to support students financially in pursuing international experiential learning.

Another challenge mentioned by graduates is the difficulty of finding employment without access to a network of professionals in the development sector. IDS graduates placed very heavy emphasis on the importance of building a professional network as a crucial factor in finding a job-and in their comments, very large numbers underlined the value of experiential learning for building those networks. In addition to offering more opportunities for experiential learning, IDS programs can find other ways to support students and provide opportunities for building professional relationships and networks. Some programs have active Facebook pages that connect the graduates of their university, and others host events for current students to interact and network with program alumni. But it appears that IDS programs could do more to help students both develop strong networking skills and create opportunities for professional networking among IDS students and graduates in Canada.

The open-ended data indicate that the perceived benefits of different experiential learning options on educational outcomes are all very positive and roughly of the same magnitude. However, in terms of getting a job and breaking into the international development sector, internships and co-op programs are mentioned most often in relation to career success. These types of "work-integrated learning" opportunities, which include a workplace-based component, are perceived as being more beneficial for finding work than other types of experiential learning programs. The reason for this, according to graduates, is that co-ops and internships tend to look more like "real work experience" when listed on a CV, compared to, for instance, volunteer work, service-based learning, fieldwork, or even international experiences:

My degree in IDS set me up for success in helping to shape my worldview. It did not give me the concrete skills that I use in my job today (budgeting, project management, financial analysis), but it did give me a good network of friends, a greater understanding of critical thinking and a stronger appreciation for issues faced in the developing world. When I've interviewed for jobs, the name of the school that I went to and my post-graduation CIDA internship are what people ask me about. 
I've never actually been asked in a job interview about my educational experience. Hiring is done based on work experience. (Respondent 40)

My master's was very useful for learning how to conduct informational interviews, the importance of networking to find a job, and was very practical with the co-op component. (Respondent 428)

Co-op was the most useful experience, better than the program itself. I did a coop in the CEO's office of a government department with 40,000 employees. I was hired as of graduation to work full-time in a level about three levels above those where my peers were hired. (Respondent 49)

This perception may be due in part to false notions about what actually qualifies as relevant work experience in the eyes of employers. Research by Gardner et al. (2008), previously mentioned, finds that students are often unable to articulate the value or relevance of their international experiences to employers when asked to do so in an interview setting. Universities could do more to help students understand and communicate the skills and competencies they develop from participating in international educational experiences.

International opportunities like study abroad and volunteer abroad were also mentioned often by graduates in the open-ended data in relation to career success. Graduates consider international opportunities as valuable for personal growth and for gaining the "international experience" now required for most entry-level jobs in the international development sector. However, graduates did not consider international opportunities as a useful strategy for obtaining "real work experience" or establishing a professional network. This finding mirrors research conducted by Kramer and Usher (2011), which finds there are perceived comparative benefits to workplace-based learning experiences, like co-op and internships, versus other kinds of practice-based learning in which students can participate-such as teaching and research assistantships, fieldwork, and volunteering. In terms of the institutional and policy implications of this finding, Kramer and Usher recommend that universities and colleges consider expanding workplace-based opportunities when deciding how to allocate resources for experiential learning. Of course, for IDS programs there are important practical and strategic reasons to provide students with international learning opportunities, but program administrators and professors may want to reflect on the perceived value of work-integrated learning for improving graduate employment outcomes in the new global economy (Study Group on Global Education, 2017).

\section{Conclusion}

The data presented in this paper provide important insight into the relationship between experiential learning and career outcomes for IDS graduates. Study findings confirm that there is a perceived positive relationship in all forms of experiential learning in terms of helping IDS graduates be competitive in the job market and access jobs in the development sector, with slightly more importance given to internships and co-op placements, followed by international opportunities. Overwhelmingly, IDS graduates perceive experiential learning as beneficial for furthering their knowledge learned in the classroom, developing new skillsets, and networking with potential employers. These perceptions do need to be interpreted with caution, however, as many graduates who emphasized the 
importance of experiential learning opportunities did not actually participate in them. Moreover, there are considerable structural barriers facing students without the economic means to participate in experiential learning programs, which effectively constitute unpaid work, and can be costly if they involve international travel. Graduates also recognize that the conditions of the job market play a large role in determining career outcomes and career success-and according to graduates, the international development job market in Canada is currently characterized by precarious and low-paying contract work. They recognize, as Sagen, Dallam, and Laverty (2000) conclude in their study on the effects of career preparation experiences on the employment outcomes of college graduates, that "there exists no single key to career preparation for employment" (p. 763).

With this in mind, we can take steps to optimize the value of experiential learning programs run by Canadian IDS programs. For IDS professors and administrators, the findings presented are important for improving the design and delivery of Canadian IDS programs, particularly in relation to the number and types of experiential learning opportunities offered. As IDS students debate whether to pursue in-course, practicum, and co-op options, and IDS program administrators grapple with decisions about how to allocate scarce resources to study abroad and experiential learning programs, it is useful to reflect on the relative importance that IDS graduates place on forms of work-integrated and international learning opportunities in particular for gaining necessary experience and networking with potential employers. "In setting their curriculum," write White and Devereux (2017), "universities [must also] try to find the balance between the desires of students for theoretical grounding and practical skills for a career in development, while simultaneously trying to instill critical thinking" (p. 7). To strike this balance, IDS decision makers need to have a realistic understanding of the opportunities and constraints associated with different forms of experiential learning. In particular, they should consider the particular importance that IDS graduates place on workplace-based learning experiences, like co-op placements and internships, for developing their subsequent career paths. The research findings also suggest that IDS programs may need to provide more guidance to students on how to articulate what they learn through experiential learning programs, as well as other courses, in ways that resonate with employers. Collecting updated information on the career outcomes and post-graduation experiences of IDS alumni across Canada will remain an important strategy for designing effective and market-responsive experiential learning programs.

For current IDS students, feedback from IDS graduates suggests that they should take advantage of all the educational opportunities they can while in university, whether they are degree requirements or not. Not only do these programs help students develop the competences that are highly sought after by development organizations, they also provide opportunities for building professional networks-and these are the two most important factors that IDS graduates identified for finding a job in their field. This is something that IDS students can begin while in university, by volunteering with international development and related organizations, and by recognizing that professional connections will play a crucial role in their future career paths.

\section{Acknowledgments}

The authors wish to thank the International Development Research Centre (IDRC) for its support. 


\section{References}

Astin, A., Vogelgesang, L., Ikeda, E., \& Yee, J. (2000). Executive summary: How service learning affects students. Los Angeles: Higher Education Research Institute, University of California at Los Angeles. Retrieved from http://www.wcu.edu/WebFiles/ PDFs/howservicelearningaffectsstudents.pdf

Association of Universities and Colleges of Canada (AUCC). (2014). Canada's universities and the world: AUCC internationalization survey. Ottawa, ON: Universities Canada. Retrieved from https://www.univcan.ca/wp-content/uploads/2015/o7/ internationalization-survey-2014.pdf

Bennett, M.J. (2009). Defining, measuring, and facilitating intercultural learning: A conceptual introduction to the Intercultural Education double supplement. Intercultural Education, 2O(Suppl. 1), 1-13.

Billett, S. (2011). Curriculum and pedagogical basis for effectively integrating practice-based experiences. Sydney: Australian Learning and Teaching Council. Retrieved from https://www.vu.edu.au/sites/default/files/CCLT/pdfs/billett-wil-report.pdf

Bond, S., Girgrah, A., Burrow, J., Ingersoll, M., Vandermuhlen, C. Spaling, M., \& Areemanpattnil, S. (2009). World of learning: Canadian post-secondary students and the study abroad experience. Ottawa, ON: Canadian Bureau for International Education. Retrieved from http://cbie.ca/wp-content/uploads/2016/o6/20100520_ WorldOfLearningReport_e1.pdf

Bowen, T. (2016). Depicting the possible self: Work-integrated learning students' narratives on learning to become a professional. Asia-Pacific Journal of Cooperative Education, 17(4), 399-411.

Brown, E. J. (2015). Understanding and engaging with development through international volunteering. Journal of International Development, 30, 102-117. https:// doi.org/10.1002/jid.3145

Canadian Bureau for International Education (CBIE). (2014). A world of learning: Canada's performance and potential in international learning. Retrieved from http:// net.cbie.ca/download/CBIE\%20Flagship\%202014\%20E\%20-\%20WEB\%20RES\%2O final.pdf

Canadian Bureau for International Education (CBIE). (2016). Facts and figures. Retrieved from http://cbie.ca/media/facts-and-figures/

Clayton, P. H., Bringle, R. G., \& Hatcher, J. A. (Eds.). (2013). Research on servicelearning: Conceptual frameworks and assessment. Sterling, VA: Stylus.

Dall'Alba, G. (2009). Learning professional ways of being: Ambiguities of becoming. Educational Philosophy and Theory, 41(1), 34-45.

Downey, J., Kalbfleisch, J., \& Truman, R. (2002). Co-operative education: Greater benefits, greater costs. Toronto, ON: Ministry of Training Colleges and Universities. Retrieved from http://www.watcace.uwaterloo.ca/CostBenefitCo-opStudyFinal.pdf 
Eames, C., \& Coll, R. (2010). Cooperative education: Integrating classroom and workplace learning. In S. Billett (Ed.), Learning through practice: Professional and practice-based learning (pp. 180-196). Dordrecht, Germany: Springer.

Eyler, J., \& Giles, D. (1999). Where's the learning in service-learning? San Francisco, CA: Jossey-Bass.

Eyler, J. S., Giles, D. E., Stensen, C. M., \& Gray, C. J. (2001). At a glance: What we know about the effects of service-learning on college students, faculty, institutions, and communities, 1993-200o (3rd ed.). Washington, DC: Learn and Serve America, National Service Learning Clearinghouse.

Fee, A., \& Gray, S. (2011). Fast-tracking expatriate development: The unique learning environments of international volunteer placements. The International Journal of Human Resource Management, 22(3), 530-552.

Ferguson, S., \& Wang, S. (2014). Graduating in Canada: Profile, labour market outcomes and student debt of the class of 2009-2010. Ottawa, ON: Statistics Canada. Retrieved from http://www.statcan.gc.ca/pub/81-595-m/81-595-m2014101-eng.htm

Gardner, P., Gross, L., \& Steglitz, I. (2008). Unpacking Your Study Abroad Experience: Critical Reflection for Workplace Competencies (CERI Research Brief Vol. 1, Issue 1). Retrieved from http://ceri.msu.edu/publications/pdf/brief1-2008final.pdf

Grantham, K. (in press). Assessing North-South student mobility in Canadian university strategic plans: Instrumentalist versus transformational approaches in higher education. Journal of Global Citizenship and Equity Education, 6(1).

Jackson, D. (2013). The contribution of work-integrated learning to undergraduate employability skill outcomes. Asia-Pacific Journal of Cooperative Education, 14(2), 99115 .

Jameson, J. K., Clayton, P. H., \& Ash, S. L. (2013). Conceptualizing, assessing, and investigating academic learning in service learning. In P. H Clayton, R. G. Bringle, \& J. A. Hatcher (Eds.), Research on service learning: Conceptual frameworks and assessment (Vol. 2A, pp. 85-110). Sterling, VA: Stylus.

Jorgenson, S., \& Shultz, L. (2012). Global citizenship education (GCE) in postsecondary institutions: What is protected and what is hidden under the umbrella of GCE? Journal of Global Citizenship and Equity Education, 2(1), 1-18.

Karim-Haji, F., Roy, P. \& Gough, R. (2016). Building ethical global engagement with host communities: $N$-S collaborations for mutual learning and benefit. Resource Guide presented at the 1oth Annual Global Internship Conference, Boston, MA, USA. Retrieved from http://www.pamelaroy.net/uploads/5/o/8/2/50825751/karim-haji_roy gough_2016_resource_guide.pdf

Kock, T., \& Weeks, W. (2015). Job-Related Competencies Desired By Those Who Hire International Development Consultants. Journal of International Agriculture and Extension Education, 22(1), 21-34.

Kolb, D. (1981). Learning styles and disciplinary differences. In A. Chickering (Ed.), The modern American college: Responding to the new realities of diverse students and a changing society (pp. 232-253). San Francisco, CA: Jossey-Bass. 
Kolb, D. (1984). Experiential learning: Experience as the source of learning and development. Englewood Cliffs, NJ: Prentice Hall.

Kolb, D., \& Fry, R. (1974). Toward an applied theory of experiential learning. Boston, MA: M.I.T. Alfred Sloan School of Management.

Kramer, M., \& Usher, A. (2011). Work-Integrated Learning and Career-Ready Students: Examining the Evidence. Toronto, ON: Higher Education Strategy Associates.

Larsen, M. (2015). Internationalization in Canadian higher education: A case study of the gap between official discourses and on-the-ground realities. Canadian Journal of Higher Education, 45(4), 101-122.

Lewin, R. (2009). Introduction: The quest for global citizenship through study abroad. In R. Lewin (Ed.), The handbook of practice and research in study abroad (pp. xiii-xxii). New York, NY: Routledge.

Lockeman, K. S., \& Pelco, L. E. (2013). The relationship between service-learning and degree completion. Michigan Journal of Community Service Learning, 2O(1), 18-30.

MacDonald. K. (2014). (De)colonizing pedagogies: An exploration of learning with students volunteering abroad. In R. Tiessen \& R. Huish (Eds.), Globetrotting or global citizenship: Perils and potential of international experiential learning (pp. 209-229). Toronto, ON: University of Toronto Press.

MacDonald, K., \& Tiessen, R. (in press). Introduction to special issue: The practice, politics and possibilities of globally-engaged experiential learning in diverse contexts. The Journal of Global Citizenship and Equity Education.

Martin, A., Rees, M., \& Edwards, M. (2011). Work-integrated learning. A template for good practice: Supervisors' reflections. Wellington, NZ: Ako Aotearea. Retrieved from https://ako.ac.nz/knowledge-centre/work-integrated-learning/work-integratedlearning-a-template-for-good-practice-2/

Mate, S., \& Ryan, M. (2015). Learning through work: How can a narrative approach to evaluation build students' capacity for resilience? Asia Pacific Journal of Cooperative Education, 16(3), 153-161.

Matthews, P. H., Dorfman, J. H., \& Wu, X. (2015). The impacts of undergraduate service-learning on post-graduation employment outcomes. The International Journal of Research on Service-Learning and Community Engagement, 3(1), 1-16.

McRae, N., Ramji, K., Lu, L., \& Lesperance, M. (2016). Developing global-ready graduates: The CANEU-COOP experience.Asia-Pacific Journal ofCooperative Education, Special Issue, 17(4), 377-386.

Nevison, C., Drewery, D., Pretti, J., \& Cormier, L. (2016). Using learning environments to create meaningful work for co-op students. Higher Education Research \& Development, $36(4), 807-822$.

Nevison, C., \& Pretti, T. (2016). Exploring cooperative education students' performance and success: A case study. Asia-Pacific Journal of Cooperative Education, 17(3), 325-335.

Nystrom, S. (2009). The dynamics of professional identity formation: Graduates' transitions from higher education to working life. Vocations and Learning, 2(1). 1-18. 
Palacios, C. (2010). Volunteer tourism, development, and education in a post-colonial world: Conceiving global connections beyond aid. Journal of Sustainable Tourism, 18(7), 861-878.

Perold, H., Graham, L. A., Mavungu, E. M., Cronin, K., Muchemwa, L., \& Lough, B. J. (2012). The colonial legacy of international voluntary service. Community Development Journal, 48(2), 179-196.

Qiubo, Y., Shibin, W., \& Zha, Q. (2016). Canada's Industry-University Co-op Education Accreditation System and Its Inspiration for the Evaluation of China's Industry-UniversityInstitute Cooperative Education. Chinese Education \& Society, 49. 182-197.

Sagen, H., Dallam, J., \& Laverty, J. (2000). Effects of career preparation experiences on the initial employment success of college graduates. Research in Higher Education, 41(6), 753-767.

Sattler, P., and Peters, J. (2013). Work-integrated learning in Ontario's postsecondary sector: The experience of Ontario graduates. Toronto, ON: Higher Education Quality Council of Ontario. Retrieved from http://www.heqco.ca/SiteCollectionDocuments/ WIL_Experience_ON_Graduates_ENG.pdf

Sauntson, H., \& Morrish, L. (2010). Vision, values and international excellence: The "products"

that university mission statements sell to students. In M. Molesworth, E. Nixon, \& R. Scullion (Eds.), The marketisation of higher education and the student as consumer (pp. 73-85). New York, NY: Routledge.

Sharpe, E. (2015). Colonialist tendencies in education abroad. International Journal of Teaching and Learning in Higher Education, 27(2), 227-234.

Sides, C., \& Mrvica, A. (2007). Internships: Theory and practice. Amityville, NY: Baywood Publishing

Sternberg, R.J. (2013, June 17). Giving employers what they don't really want. The Chronicle of Higher Education. Retrieved from http://chronicle.com/article/GivingEmployers-What-They/139877/

Stirling A., Kerr G., MacPherson E., Banwell J., Bandealy A., \& Battaglia A. (2017). Do postsecondary internships address the four learning modes of experiential learning theory? An exploration through document analysis. Canadian Journal of Higher Education, 47(1), 27-48.

Study Group on Global Education. (2017). Global education for Canadians: Equipping young Canadian to succeed at home and abroad. Ottawa, ON: Study Group on Global Education. Retrieved from: http://goglobalcanada.ca

Thirolf, K. (2014). Male college student perceptions of intercultural and study abroad programs. Journal of Students Affairs Research and Practice, 51(3), 246-258.

Thomas, L., \& Chandrasekera, U. (2014). Uncovering what lies beneath: An examination of power, privilege, and racialization in international social work. In R. Tiessen \& R. Huish (Eds.), Globetrotting or global citizenship: Perils and potential of international experiential learning (pp. 90-111). Toronto, ON: University of Toronto Press. 
Tiessen, R. (2012). Motivations for learning/volunteer abroad programs: Research with Canadian youth. Journal of Global Citizenship and Equity Education, 2(1), 1-21.

Tiessen, R. (2018). Learning and volunteering abroad for development: Unpacking host organization and volunteer rationales. New York, NY: Routledge.

Tiessen R., \& Cameron, J. (2017). The career paths of IDS graduates in Canada. Ottawa, ON: Canadian Association for the Study of International Development. Retrieved from https://idsemployment.weebly.com/uploads/4/5/2/2/45224335/national_ report_english_final.pdf

Tiessen, R., \& Heron, B. (2012). Volunteering in the developing world: The perceived impacts of Canadian youth. Development in Practice, 22(1), 44-56.

Tiessen, R., \& Huish, R. (2014). International experiential learning and global citizenship. In R. Tiessen \& R. Huish (Eds.), Globetrotting or global citizenship: Perils and potential of international experiential learning (pp. 3-20). Toronto, ON: University of Toronto Press.

Universities Canada. (2016a). Global possibilities: An examination of North-South student mobility programs offered through Canadian universities. Ottawa, ON: Universities Canada.

Universities Canada. (2016b). Ethics in North-South student mobility. Ottawa, ON: Universities Canada. Retrieved from: https://www.univcan.ca/wp-content/ uploads/2015/07/north-south-student-mobility-ethics-nov-2016.pdf

Warren, J. L. (2012). Does service-learning increase student learning? A meta-analysis. Michigan Journal of Community Service Learning, 18(2), 56-61.

White, P., \& Devereux, P. (2017). "Learning" development. Forum for Development Studies, 45(1), 119-141. https://doi.org/10.1080/08039410.2017.1393458

\section{Contact Information}

Rebecca Tiessen

University of Ottawa

Rebecca.Tiessen@uottawa.ca

Rebecca Tiessen is University Chair in Teaching and Full Professor in the School of International Development and Global Studies at the University of Ottawa. Correspondence for this article can be directed to her.

Kate Grantham is Research Associate with the Institute for the Study of International Development at McGill University.

John Cameron is Associate Professor of International Development Studies at Dalhousie University. 